ANDRZEJ WiELOŃSKI

Uniwersytet Warszawski

\title{
Wielkość i struktura eksportu miarą konkurencyjności polskiego przemysłu
}

W latach 2004-2008 wartość polskiego eksportu zwiększyła się z 59698 mln euro (w 2000 r. - $34373 \mathrm{mln}$ euro) do $118722 \mathrm{mln}$ euro, tj. w przeliczeniu na jednego mieszkańca - z 1564 euro (w 2000 r. - 827 euro) do 3050 euro. Wartość eksportu w przeliczeniu na jednego mieszkańca jest nadal relatywnie niska w stosunku do potencjału gospodarczego Polski. Dla porównania: Irlandia - 20993 euro, Czechy - 7388 euro, Słowacja - 6158 euro, Węgry - 5918 euro.

Wzrost eksportu po 2004 r. to w dużym stopniu tzw. efekt kreacji handlu związany z uczestnictwem w rynku wewnątrzwspólnotowym. Liberalizacja wymiany handlowej została zapoczątkowana w okresie przedakcesyjnym. Najpierw eliminowano cła oraz opłaty o podobnych do ceł skutkach, a także ograniczenia ilościowe w handlu artykułami przemysłowymi (ostatnie cła na towary przemysłowe zniesiono na dwa lata przed wstąpieniem Polski do Unii Europejskiej). Na wzrost eksportu istotny wpływ miał również zwiększony napływ bezpośrednich inwestycji zagranicznych oraz wewnętrzna restrukturyzacja przedsiębiorstw wymuszona koniecznością dostosowania standardów technicznych i technologicznych do wymogów unijnych.

W czwartym kwartale 2008 r. (pierwszy raz od 1999 r.) wystapił spadek eksportu. Wartość eksportu wyniosła 26213 mln euro i w porównaniu z analogicznym okresem w 2007 r. była niższa o 2413 mln euro. Na spadek eksportu decydujący wpływ miało pogorszenie koniunktury na głównych rynkach unijnych, jak również rynkach Europy Środkowo-Wschodniej, w tym zwłaszcza Ukrainy. Efektem kryzysu finansowego, który (za pośrednictwem instytucji finansowych zaangażowanych w obrót obligacji zabezpieczonych kredytami hipotecznymi) dotarł ze Stanów Zjednoczonych do Europy, stało się zmniejszenie aktywności realnej gospodarki. W efekcie wartość polskiego eksportu w 2009 r. wyniosła 99827 mln euro i w porównaniu z rokiem poprzednim była niższa o $21255 \mathrm{mln}$ euro.

Od początku lat 90. XX w. głównym partnerem handlowym Polski stała się Unia Europejska. W 2003 r., a więc ostatnim roku sprzed jej rozszerzenia o dziesięć nowych krajów, na Unię Europejską przypadało 68,8\% polskiego eksportu. Na koniec 2004 r., a więc po rozszerzeniu, jej udział w eksporcie (dostawie wewnątrzwspólnotowej, wywozie) zwiększył się do $79,2 \%$.

W 2008 r. obroty handlowe z Unią Europejską stanowiły 77,8\% polskiego eksportu (w tym Niemcy - 25\%). Saldo obrotów handlowych było dodatnie. Spośród pozostałych kra- 
jów znaczącą rolę odgrywają: Rosja, na którą przypada 5,2\% polskiego eksportu, i Ukraina $-3,8 \%$. Obroty handlowe z Rosją charakteryzuje duży deficyt spowodowany importem ropy naftowej i gazu ziemnego, natomiast o dodatnim saldzie obrotów z Ukrainą decyduje eksport produkowanych w FSO w Warszawie samochodów osobowych oraz nadwozi do montażu, a od pierwszej połowy 2009 r. również eksport artykułów rolno-spożywczych.

Niekorzystnym zjawiskiem w dotychczasowej strukturze geograficznej polskiego eksportu jest zbyt duże jego uzależnienie od rynków krajów europejskich, przy równoczesnym niewielkim udziale rynków krajów pozaeuropejskich, w tym zwłaszcza zaliczanych do tzw. rynków wschodzących. Przykładem są Chiny (trzeci pod względem obrotów handlowych kraj na świecie), na który przypada zaledwie 1,1\% polskiego eksportu, natomiast aż 9,3\% importu. Duży deficyt obrotów handlowych spowodowany jest importem odzieży, obuwia i zabawek (konkurujących z wyrobami krajowymi) oraz sprzętu radiowo-telewizyjnego, telekomunikacyjnego i komputerów.

W strukturze polskiego eksportu (według sekcji Międzynarodowej Standardowej Klasyfikacji Handlu) największy udział mają maszyny, urządzenia i sprzęt transportowy 42,98\% (w 1995 r. - 21,1\%); deficyt w handlu maszynami i urządzeniami rekompensuje nadwyżka w handlu sprzętem transportowym. Pojazdy nieszynowe oraz ich części i akcesoria, statki powietrzne oraz jednostki pływające stanowią 17,36\% wartości polskiego eksportu, w tym $14,43 \%$ to wyroby przemysłu motoryzacyjnego (ryc. 1).

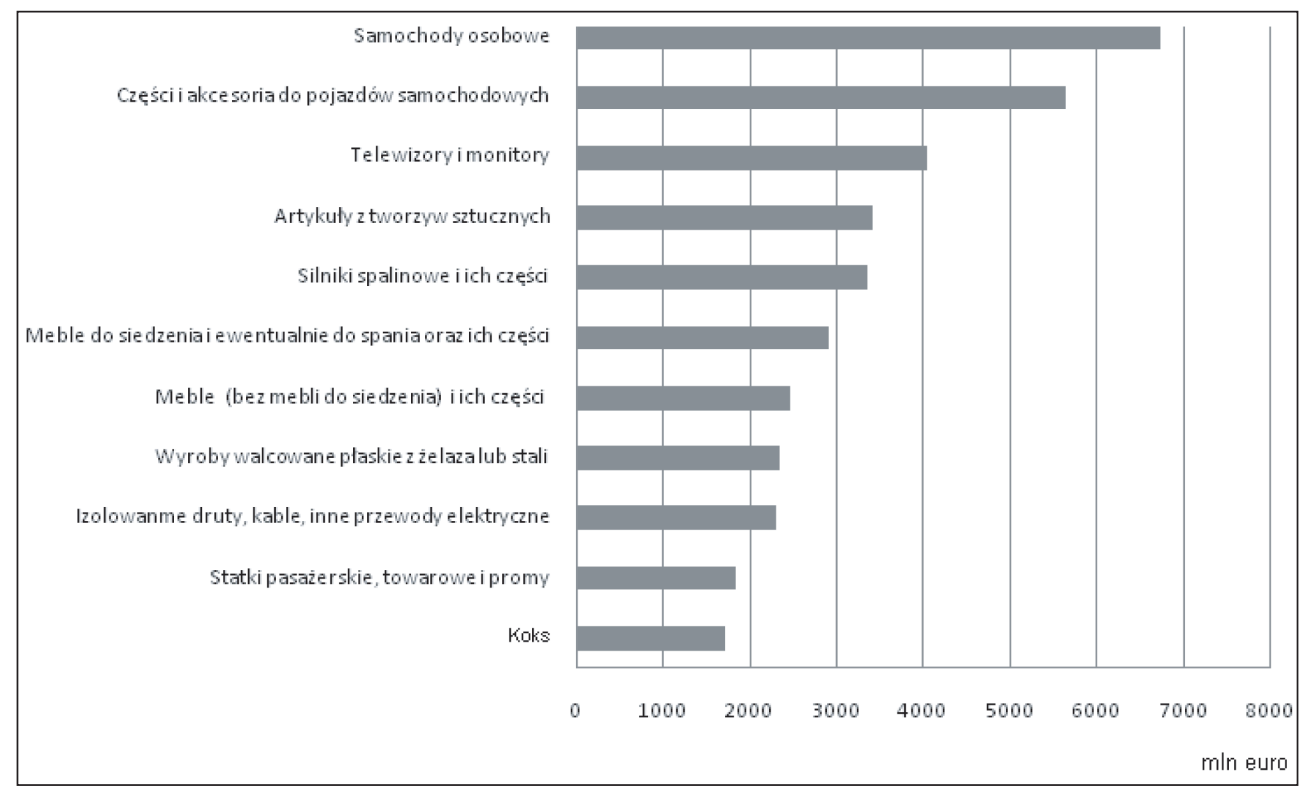

Ryc. 1. Główne towary w eksporcie

Źródło: Opracowanie własne na podstawie danych GUS

Wśród rodzajów działalności (według Polskiej Klasyfikacji Działalności) największym udziałem eksportu w przychodach ze sprzedaży, przekraczającym 65\%, charakteryzują się producenci pojazdów mechanicznych, przyczep i naczep oraz pozostałego sprzętu transportowego. W 2008 r. wśród dziesięciu największych eksporterów (pomijając PKN Orlen 
- Płock, w którym pomimo wysokiej wartości, eksport stanowi zaledwie 28\% wartości sprzedaży, natomiast znaczący w nim udział mają dostawy paliw do zagranicznych stacji koncernu) znalazło się pięć przedsiębiorstw reprezentujących ten rodzaj działalności: producenci samochodów osobowych i osobowo-towarowych Fiat Auto Poland - Bielsko-Biała (produkcja samochodów odbywa się w fabryce w Tychach; wartość eksportu - $12950 \mathrm{mln}$ zł, udział eksportu w sprzedaży - 86\%) i Volkswagen Poznań - (7 555 mln zł, 95\%), producent silników Volkswagen Motor Polska - Polkowice (2 $671 \mathrm{mln}$ zł, 70\%), Faurecia Fotele Samochodowe - Grójec (2 616 mln zł, 76\%) oraz producent silników i skrzyń biegów Fiat-GM Powertrein Polska - Bielsko-Biała (2 $508 \mathrm{mln}$ zł, 65\%). Do grupy największych eksporterów należały również: KGHM Polska Miedź - Lubin (7 $872 \mathrm{mln}$ zł, 62\%), producenci telewizorów i monitorów LG Electronics Mława - Mława (3 $750 \mathrm{mln}$ zł, 93\%) i LG Electronics Wrocław - Biskupice Podgórne (3 $241 \mathrm{mln}$ zł, 92\%), producent sprzętu oświetleniowego Philips Lighting Poland - Piła (3 325 mln zł, 88\%) oraz Koksownia Przyjaźń $2231 \mathrm{mln} z ł, 86 \%)$.

Wśród dziesięciu największych eksporterów przeważają przedsiębiorstwa z kapitałem zagranicznym. Są one m.in. mniej wrażliwe na aprecjację złotego, gdyż znacząca część eksportu odbywa się w ramach tzw. eksportu wewnętrznego (handlu wewnątrzkorporacyjnego). Dziewięć spośród dziesięciu przedsiębiorstw - największych eksporterów, zlokalizowanych jest na terenie województw: śląskiego, dolnośląskiego, mazowieckiego i wielkopolskiego, z których pochodzi prawie $60 \%$ polskiego eksportu.

Na wielkość i strukturę polskiego eksportu znaczący wpływ mają przedsiębiorstwa z kapitałem zagranicznym. W latach 2000-2008 ich udział w eksporcie zwiększył się z 44\% do ponad 60\%. Również dzięki przedsiębiorstwom z kapitałem zagranicznym zmienia się struktura eksportu, w której zwiększa się udział wyrobów wysoko przetworzonych, w tym głównie zaliczanych do wyrobów średnio-wysokiej techniki - 44,5\%. Te ostatnie, wśród których znaczący udział mają: samochody osobowe, samochody osobowo-towarowe, silniki wysokoprężne, części i akcesoria samochodowe, autobusy, samochody ciężarowe, przyczepy i naczepy, pojazdy specjalne oraz podwozia z silnikami stały się specjalizacją eksportową Polski.

Nadal niekorzystnym zjawiskiem w strukturze polskiego eksportu jest niewielki udział wyrobów wysokiej techniki - 4,2\% (w 2000 r. - 2,9\%). Dla porównania: Unia Europejska - 16,7\%, Irlandia - 29,1\%, Węgry - 21,7\%, Czechy - 13,7\%, Słowacja - 4,6\%. Jest to głównie efekt bardzo małych nakładów przeznaczanych na sferę badawczo-rozwojową i jej niedostatecznych powiązań z sektorem przedsiębiorstw. W Polsce wydatki przedsiębiorstw na badania naukowe i prace rozwojowe w relacji do produktu krajowego brutto wynoszą 0,18\%. Dla porównania: w Unii Europejskiej - 1,17\%.

Niekorzystnym zjawiskiem w strukturze polskiego eksportu jest również brak utrwalonych, powszechnie kojarzonych z Polską marek towarowych w grupie wyrobów wysokiej techniki. Taką pozycję, i to na rynkach niszowych, zajmują głównie marki towarowe wyrobów tradycyjnych, np. Wedel - na rynku najwyższej jakości wyrobów czekoladowych czy Belvedere - na rynku wódek luksusowych. W obu przypadkach, w znacznym stopniu jest to również efekt światowej promocji prowadzonej przez obecnych właścicieli tych marek, tj. lidera światowego rynku słodyczy Cadbury (w przypadku marki Wedel) i lidera światowego rynku dóbr luksusowych Louis Vuitton Moët Henessy (w przypadku marki Belvedere).

W 2004 r., w którym nastąpiło rozszerzenie Unii Europejskiej, do Polski napłynęło 10237 mln euro, tj. najwięcej od 2000 r., kiedy to kapitał zagraniczny zainwestował 
10334 mln euro. Łącznie w latach 2001-2008 średnioroczny napływ bezpośrednich inwestycji zagranicznych przekraczał $9500 \mathrm{mln}$ euro. Wprawdzie napływ bezpośrednich inwestycji zagranicznych pociaga za sobą dodatkowy import, jednak skumulowany długookresowy efekt netto, czyli różnica między eksportem wygenerowanym przez daną inwestycję a importem niezbędnym do jej funkcjonowania, jest dodatni i wynosi ok. 0,8 mld euro od każdego zainwestowanego 1 mld euro (Instytut Badań Rynku, Konsumpcji i Koniunktur 2007).

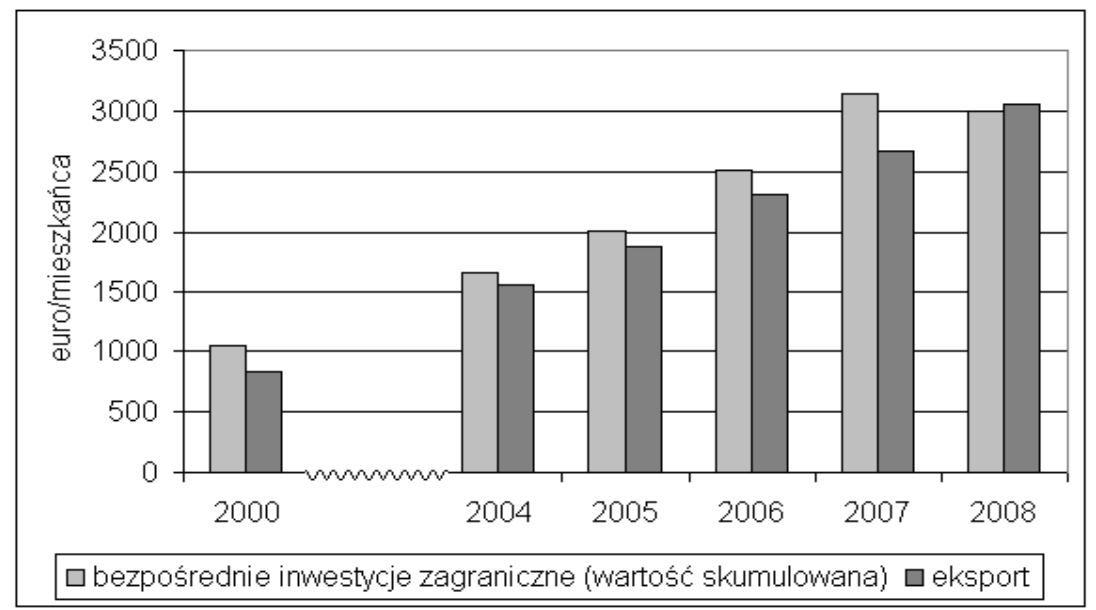

Ryc. 2. Eksport i bezpośrednie inwestycje zagraniczne

Źródło: Opracowanie własne na podstawie danych NBP

W 2008 r. skumulowana wartość bezpośrednich inwestycji zagranicznych (w przeliczeniu na jednego mieszkańca) osiaggnęła 3005 euro (ryc. 2). Dla porównania: Czechy 6466 euro, Węgry - 6624 euro, Słowacja - 4685 euro.

Po przystappieniu do Unii Europejskiej zwiększyło się zainteresowanie inwestycjami w Polsce ze strony koncernów motoryzacyjnych i elektronicznych z Japonii oraz koncernów elektronicznych z Korei Południowej.

W latach 2005-2008 spośród projektów przemysłowych, których realizację zadeklarowali inwestorzy zagraniczni, do największych należały: produkcja opon do samochodów ciężarowych i autobusów (Bridgestone - Stargard Szczeciński), produkcja sprzętu komputerowego (Dell - Łódź), produkcja modułów, telewizorów LCD (Sharp - Łysomice k. Torunia), produkcja skrzyń biegów (Toyota - Wałbrzych), produkcja telewizorów LCD (Toshiba Kobierzyce), produkcja ekranów ciekłokrystalicznych LCD (LG Philips - Kobierzyce), produkcja samochodów ciężarowych (MAN - Niepołomice), produkcja opon samochodowych (Michelin - Olszyn), produkcja sprzętu RTV i AGD (LG - Kobierzyce), produkcja sprzętu AGD (Electrolux - Oława i Świdnica, Indesit - Radomsko), produkcja cementu (Lafarge - Bielawy k. Barcina), produkcja telewizorów i paneli LCD (Jabil - Kwidzyń) i produkcja gumy do żucia (Cadbury - Skarbmierz k. Brzegu).

Inwestycje te potwierdzają, że Polska jest krajem atrakcyjnym dla kapitału zagranicznego inwestującego w sektor motoryzacyjny oraz w produkcję sprzętu AGD i RTV. Inwestycjom producentów dóbr finalnych towarzyszą inwestycje producentów komponentów (tab. 1). 
Tab. 1. Produkcja wybranych wyrobów przemysłowych

\begin{tabular}{|l|l|l|l|l|l|l|l|l|}
\hline \multicolumn{1}{|c|}{ Wyszczególnienie } & $\begin{array}{c}\text { Jednostki } \\
\text { miary }\end{array}$ & 1990 & 2000 & 2005 & 2006 & 2007 & 2008 & 2009 \\
\hline $\begin{array}{l}\text { Samochody osobowe } \\
\text { ogólnego przeznaczenia }\end{array}$ & $\begin{array}{l}\text { szt./10 000 } \\
\text { ludności }\end{array}$ & 70,1 & 139,0 & 142,0 & 165,6 & 182,3 & 221,0 & 215,0 \\
\hline $\begin{array}{l}\text { Odbiorniki telewizyjne łącznie } \\
\text { z monitorami ekranowymi, } \\
\begin{array}{l}\text { Z wyjątkiem stosowanych } \\
\text { do komputerów }\end{array}\end{array}$ & $\begin{array}{l}\text { szt./1000 } \\
\text { ludności }\end{array}$ & 19,7 & 164,0 & 176,0 & 247,0 & 490,0 & 438,1 & 613,0 \\
\hline $\begin{array}{l}\text { Chłodziarki i zamrażarki } \\
\text { typu domowego }\end{array}$ & $\begin{array}{l}\text { szt./1000 } \\
\text { ludności }\end{array}$ & 15,9 & 18,1 & 43,9 & 51,8 & 61,0 & 59,1 & 49,0 \\
\hline $\begin{array}{l}\text { Maszyny pralnicze typu } \\
\text { domowego }\end{array}$ & $\begin{array}{l}\text { szt./1000 } \\
\text { ludności }\end{array}$ & 12,7 & 14,7 & 38,8 & 42,9 & 52,4 & 65,6 & 86,0 \\
\hline
\end{tabular}

Źródło: Opracowanie własne na podstawie danych GUS

$\mathrm{Na}$ wielkość i strukturę eksportu mogą mieć również wpływ inwestycje zrealizowane w ramach offsetu, czyli zobowiązania do zainwestowania w kraju, który kupuje uzbrojenie, kapitału o określonej wartości lub zakupu w nim wyrobów i usług. Potwierdzają to doświadczenia Republiki Południowej Afryki, Izraela i przede wszystkim Finlandii, w której offset towarzyszący zakupowi samolotów wielozadaniowych F-16 doprowadził m.in. do wykreowania koncernu Nokia na światowego lidera rynku telefonii komórkowej.

W Polsce największą umowę offsetową zawarto w 2003 r. z Lockheed Martin Corporation ze Stanów Zjednoczonych, który wygrał przetarg na dostawę dla polskiego lotnictwa samolotów wielozadaniowych F-16, zobowiązując się do zainwestowania w ciagu dziesięciu lat $6028 \mathrm{mln}$ dolarów. Do końca 2008 r. zainwestował $4976 \mathrm{mln}$ dolarów. Niestety (z przyczyn leżących po obu stronach) tylko co czwarty z projektów spełniał rzeczywiste cele offsetu. Pozostałe ograniczały się do korzyści bieżących, takich jak np. poprawa sytuacji rynkowej przedsiębiorstwa (Najwyższa Izba Kontroli 2009). Największe korzyści ze zrealizowanych dotychczas zobowiązań odniosły: ZM Mesko - Skarżysko-Kamienna i WSK PZL Rzeszów - w ramach offsetu bezpośredniego oraz Lotos - Gdańsk i General Motor Manufacturing Gliwice - w ramach offsetu pośredniego. To ostatnie przedsiębiorstwo dzięki uruchomieniu w ramach umowy offsetowej produkcji Astry II Classic, a następnie Opla Zafiry II, dostarczyło w latach 2005-2008 na rynki zagraniczne 600 tys. sztuk samochodów osobowych.

W 2008 r. Polska była najczęściej wskazywaną przez inwestorów zagranicznych lokalizacją nowych inwestycji w Europie, wyprzedzając Niemcy i Rosję (Ernst \& Young 2008). Spośród nowych krajów Unii Europejskiej w grupie najatrakcyjniejszych znalazły się: Rumunia, Węgry, Bułgaria i Czechy. Niższe koszty prowadzenia działalności gospodarczej (głównie dzięki niższym kosztom pracy i niższym podatkom od przedsiębiorstw) oraz atrakcyjne położenie (w Europie Południowo-Wschodniej nad Morzem Czarnym) powodują, że przyjęte 1 stycznia 2007 r. do Unii Europejskiej Bułgaria i Rumunia stają się dla krajów Europy Środkowej, w tym dla Polski, coraz poważniejszymi konkurentami w pozyskiwaniu 
inwestorów zagranicznych. W ostatnim roku przed akcesją kapitał zagraniczny zainwestował w Rumunii 9 mld euro, w 2007 r. - 7,2 mld euro i w 2008 r. - 9,02 mld euro.

Światowy kryzys finansowy, który pod koniec 2008 r. zmniejszył aktywność realnej gospodarki, nie pozostał bez wpływu na wielkość przepływów kapitału. W 2009 r. kapitał zagraniczny zainwestował w Polsce $8384 \mathrm{mln}$ euro, tj. o 17\% mniej niż w poprzednim roku. Dla porównania: w pozostałych krajach Europy Środkowo-Wschodniej (z wyjątkiem Słowacji) wartość bezpośrednich inwestycji zagranicznych zmniejszyła się o 50-60\%. W Polsce spośród projektów przemysłowych, których realizację zapoczątkowali inwestorzy zagraniczni, do największych należały: produkcja maszyn i urządzeń przeładunkowych (Cargotec - Stargard Szczeciński) oraz projektowanie, produkcja i serwis urządzeń sterujących i monitorujących pracę, m.in. silników lotniczych i urządzeń wytwarzających energię elektryczną (Woodward Governor - Niepołomice). Równocześnie pod koniec 2009 r. Samsung Electronics podpisał przedwstępną umowę z Amiką - producentem sprzętu AGD, dotyczącą zakupu zakładów we Wronkach (Polska Agencja Informacji i Inwestycji Zagranicznych 2009).

\section{Literatura}

Polska 2009. Raport o stanie handlu zagranicznego, 2009, Ministerstwo Gospodarki, Warszawa 5 lat Polski w Unii Europejskiej, 2009, UKIE, Warszawa

\section{Volume and structure of export as a measure of competitiveness of the Polish industry}

In the years 2000-2008 the value of foreign direct investments (FDI) in Poland grew from 40, 300 million euro to 114,600 million euro. The inflow of FDI was accompanied by the increase in export. In the years 2000-2008, its value increased from 30, 373 million euro to 118,722 million euro, while the share of the enterprises with foreign capital in this export value jumped from $44 \%$ to $60 \%$. Owing to the FDI, the passenger cars and trucks, buses, spark-ignition, parts and accessories for the motor vehicles, electro-mechanical domestic appliances, television reception appliances and monitors, classified as technology - intensive, became the primary export products of Poland.

Dr hab. prof. UW Andrzej Wieloński

Uniwersytet Warszawski

e-mail: awielons@uw.edu.pl 